\title{
REDACTIONEEL
}

\section{Herstelrecht en strafrecht: naar een compendium van dwalingen?}

\author{
Bas van Stokkom
}

Veel herstelrechtdenkers verwijten het strafrecht blindelings in te zetten op punitieve interventies. Op hun beurt menen veel strafrechtdenkers dat voorstanders van het herstelrecht een rooskleurig beeld hebben van de mogelijkheden misdaad een halt toe te roepen; sommigen beweren dat het herstelrecht utopisch is, omdat het de fundamentele rol van de Staat miskent. Zo beschouwd lijken strafrecht en herstelrecht ideologische betekenissen te herbergen, opgevat als doeleinden en verwachtingen met betrekking tot de inrichting van het recht en afdoening van zaken die een vertekend beeld geven van de werkelijkheid.

Het zou een uitdaging zijn om dergelijke misleidende gedachten op een rijtje te zetten. Op die manier zou je een compendium kunnen samenstellen van claims en principes die de realiteit veronachtzamen.

Of zo'n compendium wel altijd nut en zin heeft, staat overigens te bezien. Zo blijven zich daadkrachtig noemende politici zweren bij 'prison works', al is dat door een eindeloze hoeveelheid rapporten weerlegd.

Complicerend is ook dat doctrines en ficties nuttig en zinvol kunnen zijn: vrije wil, gelijke behandeling, gelijke gevallen gelijk bestraffen, neutraliteit. Je ontkomt er niet aan deze principes - sommigen zouden zeggen: fantasieën - op te tuigen, wil je het recht legitimiteit geven en een principe als individuele verantwoordelijkheid overeind houden. Je kunt ficties overigens ook 'gewoon' zien als uitgangspunten waarnaar gestreefd moet worden.

Daarnaast is het de vraag of je wel kunt spreken over 'het' strafrecht en 'het' herstelrecht. Die stelsels kennen intern vele stromingen die vaak met elkaar op gespannen voet staan. Zo vinden aanhangers van afschrikking, incapacitatie, vergelding, resocialisering en pedagogisch straffen onderdak in het strafrecht. Het herstelrecht lijkt minder chaotisch samengesteld, hoewel er discussies gaande zijn tussen 'maximaliseerders' en 'puristen'.

Over deze onderwerpen werd gesproken op een expert-seminar herstelrecht aan de Vrije Universiteit in Amsterdam (juni 2015). Aanleiding was een artikel van rechtstheoreticus Vincent Geeraets, getiteld 'Herstelrechtelijke ficties' (Rechtsgeleerd Magazijn THEMIS 2014-2, p. 72-79), waarin hij betoogde dat enkele uitgangspunten van het herstelrecht niet waargemaakt worden. Het gaat onder meer om de aanname dat deelname aan een herstelgesprek op vrijwillige basis geschiedt. Aangezien er in de praktijk menigmaal druk en dwang wordt uitgeoefend op de deelnemers, zo redeneert Geeraets, maakt deze 'fictie' het herstelrecht repressiever dan normaal gesproken wordt aangenomen. 
In dit varianummer is een artikel van Vincent Geeraets opgenomen, alsmede de repliek daarop van Jacques Claessen. Tezamen vormen ze een filosofisch tweeluik over achterliggende veronderstellingen van recht, recht doen en het opleggen van sancties, en de morele implicaties van de misdaad voor de dader. Voor de aandachtige lezer die er goed voor wil gaan zitten, leveren de twee artikelen boeiende kost op.

Geeraets gaat eerst in op de zogenoemde oorsprongsverhalen van het strafrecht en het herstelrecht. Beide verhalen geven zijns inziens een vertekening van de sociale werkelijkheid. Terwijl strafjuristen menen dat burgerparticipatie in de context van het strafproces tot chaos leidt, staan herstelrechtdenkers op het standpunt dat herstelbemiddeling in een traditionele samenleving een harmonieus karakter heeft. Voorts bespreekt Geeraets een aanname die zowel door sommige strafrechtgeleerden (Antony Duff) als herstelrechtdenkers (Jacques Claessen) verdedigd wordt: de dader zou zich door het plegen van een misdrijf beschadigen als persoon. Hij zou zich namelijk afwenden van het goede. Volgens Geeraets hebben die denkbeelden voornamelijk een retorische functie.

In zijn uitgebreide repliek betoogt Claessen dat het strafrechtelijke en het herstelrechtelijke oorsprongsverhaal zich tot elkaar verhouden als draconisering en romantisering. Beide zijn van belang voor het denken over misdaad en recht en verwijzen niet zozeer naar historische perioden en/of plaatsen, maar naar bepaalde mens- en wereldbeelden. Wat de veronderstelde morele zelfbeschadiging betreft, wijst Claessen erop dat kwaad aanrichten gezien kan worden als een weigering het eigen ego te overstijgen en een gebrek aan sensibilisering, kortom, als egocentrisme. Hij licht dat toe vanuit mystieke denktradities.

In dit nummer is ook een explorerende bijdrage opgenomen van Bas Vogelvang en Gert Jan Slump. In dit artikel gaan zij op zoek naar de werkzame mechanismen van herstelbemiddeling, bezien vanuit de direct betrokkenen. Er komen vier sociaal-morele kernelementen aan bod: begrepen worden, angst en onrust verwoorden, stimuleren van een gevoel van rechtvaardigheid, en behoud van zelfregie. "Het effect van de bemiddeling is gebaseerd op onderlinge interactie en werkzaamheid van deze vier kernelementen, die bij zowel dader als slachtoffer 'wachten' op verwerkelijking in de communicatie." De auteurs vatten die communicatie op als een 'entrainment experience', een ritueel dat emotionele en morele effecten sorteert bij de deelnemers en verwijzen daarbij onder meer naar het recente onderzoek van Meredith Rossner. In een boekbespreking achterin dit nummer wordt dat onderzoek dieper besproken.

Ten slotte is een artikel opgenomen over de 'abolitionist' Herman Bianchi die eind 2015 overleed. Jacques Claessen kijkt terug op de man en zijn werk, en betoogt dat Bianchi samen met Nils Cristie en Louk Hulsman tot de Grote Drie van het naoorlogse denken over herstelrecht hoorde. Een treffend citaat uit het artikel van Jacques:

'De herstelrechtsdenker van vandaag is al lang niet meer de utopische abolitionist van een halve eeuw geleden. De herstelrechtsdenker van vandaag is een stuk realistischer en pragmatischer, maar ook hij heeft zeker idealen. Mijn 
ideaal wordt misschien nog wel het beste tot uitdrukking gebracht in de stelling die één van mijn studenten onlangs in het onderwijs formuleerde, toen we geïnspireerd door enkele stellingen uit Bianchi's Ethiek van het straffen aan het discussiëren waren over herstelrecht: "Strafrecht vormt een noodzakelijke aanvulling op herstelrecht."' 